\title{
Assessing the Impact of Secondary City Development on Sanitation Services: The Case of Muhanga District 2013-2017
}

\author{
Niragire Ezechiel, Jean Baptiste Safari \\ Department of Environmental Economics and Natural Resources Management, University of Lay Adventists of Kigali, Kigali, Rwanda \\ Email address: \\ ezeniragire@gmail.com (N. Ezechiel), safjean2002@yahoo.fr (J. B. Safari)
}

\section{To cite this article:}

Niragire Ezechiel, Jean Baptiste Safari. Assessing the Impact of Secondary City Development on Sanitation Services: The Case of Muhanga District 2013-2017. International Journal of Natural Resource Ecology and Management. Vol. 5, No. 3, 2020, pp. 90-101.

doi: 10.11648/j.ijnrem.20200503.12

Received: July 15, 2020; Accepted: July 29, 2020; Published: August 10, 2020

\begin{abstract}
This research was conducted on the assessment of the impact of Muhanga city development on sanitation services, the primary data regarding sanitation was collected using questionnaire survey, interviews and observation. To evaluate land use land cover situation from the year 2013 up to 2017 remote sensing techniques was used. The results from collected data showed that $65 \%$ of generated solid waste is composed by organic waste, while waste collection coverage from household level is low with a percentage of $9 \%$. The analysis of land use land cover situation showed that during the five years, settlement area increased by $8.67 \%$, the amount of waste generation is increasing with population growth, and it varied from $1,555 \mathrm{~m} 3$ in 2014 to $3,045 \mathrm{~m} 3$ in 2017. The analysis of variance (ANOVA) results shows that the amount of solid waste generated is significantly difference between the year 2014 and the year 2017. Regarding liquid waste management there are drainage systems constructed, although the survey made showed that $39.2 \%$ of households sampled highlighted that storm water is still a problem in their residential area. The obtained results evidenced that solid waste collection at household level by a private company is a new practice in the city, and the collection coverage is still low compared to city resident, consequently there is still informal dumpsite in open area across the city. The private sector needs to be more committed in sanitation services provision, and the public sector needs to be involved in sanitation infrastructures development by focusing on composting facilities as a big percentage of generated waste is biodegradable. The public sector has a direct influence on the private sector and the community, the community and the private sector need to become familiar with working together for the purpose of improving sanitation with the aim to protect the environment.
\end{abstract}

Keywords: Sanitation, Waste, City Development, Infrastructure

\section{Introduction}

World Health Organization (WHO) defines sanitation as the provision of facilities and services for the safe management of human excreta from the toilet to containment and storage and treatment onsite or conveyance, treatment and eventual safe end use or disposal. More broadly sanitation also included the safe management of solid waste, liquid and animal waste [1].

As urbanization increases, human waste increases, therefore a need for a good sanitation system is evident. The increased demand for good sanitation systems in rapidly urbanizing cities requires that proper disposal measures be implemented to keep hygiene levels high and prevent disease outbreaks. There is potential for the recycling of the sludge for energy generation purposes, as agricultural fertilizer, or simply for decomposition in the soil. The two latter potentials are already common methods of disposal for small population sized areas, however a city will need to develop a large-scale system. This entails efficient measures for collection, disposal and processing [2].

The United Nations Development Programme (2002) noted that solid waste management is ongoing problem in urban centers, The United Nations Economic and Social Commission for Asia and the Pacific, Asian Development 
Bank and the United Nations Development Programme (2007) further highlighted that the difficulties in achieving the expected Millennium Development Goals in sanitation is due to rapid population and urban growth. With the context of Rwanda in 2016, the data availed by the fourth Integrated Household Living Conditions Survey (EICV 4) access to sanitation was $83 \%$, and was expected to scale up to all at $100 \%$ and waste management systems was to be developed in cities, towns and rural areas. Key investments to be undertaken included: Development of the standards for the construction of household toilets, Construction of public toilets (public institutions, commercial premises, etc.), Construction of Kigali Centralized Sewerage System $\left(120,000 \mathrm{~m}^{3} / \mathrm{d}\right)$, Construction of Kigali fecal sludge treatment plant $\left(1000 \mathrm{~m}^{3} / \mathrm{d}\right)$, Rehabilitation and upgrading of semicentralized sewerage system in Kigali Estates, Construction of Semi centralized sewerage systems in all planned and grouped settlements and Construction of fecal sludge treatment plants and landfills in all districts [3].

For Muhanga District, according to Integrated Household Living Conditions Survey conducted by National Institute of Statistics of Rwanda, in 2014 around $79.7 \%$ of the population use improved type of sanitation and $64.2 \%$ use improved sanitation type not shared with other (EICV 4); The economic development and poverty reduction strategy urbanization target was to reach $35 \%$ of population living in urban area in the year 2020, The census data suggest that $15.9 \%$ of population in Muhanga District is urban dwellers [4].
Solid waste management has been and is a challenge for many cities in developing countries [5], the rapid urbanization and administrative and economic potential of capital cities, including the City of Muhanga, are attracting many people seeking for jobs and welfare in general. This resulted in growing demand for services including solid waste collection and the public sector is unable to deliver the service alone which required the involvement of private sector.

Therefore, poor sanitation services in developing countries created enormous government expenditures on the health sector and reduces productivity in the labor force leading to declining economic performances in developing world regions. This undermines the sustainable development of cities and towns in developing countries and subsequently leads to their under development. Therefore, developing economical, acceptable, technically flexible, and environmentally-friendly sanitation technology for the next generation requires research into sanitation technologies development.

\section{Materials and Methods}

According to [6], five prominent designs are outlined and include the experimental design, cross-sectional design also known as survey research, longitudinal design, case study and comparative design. The research design for this study was cross-sectional for collecting data regarding sanitation services and was be designed as follow:

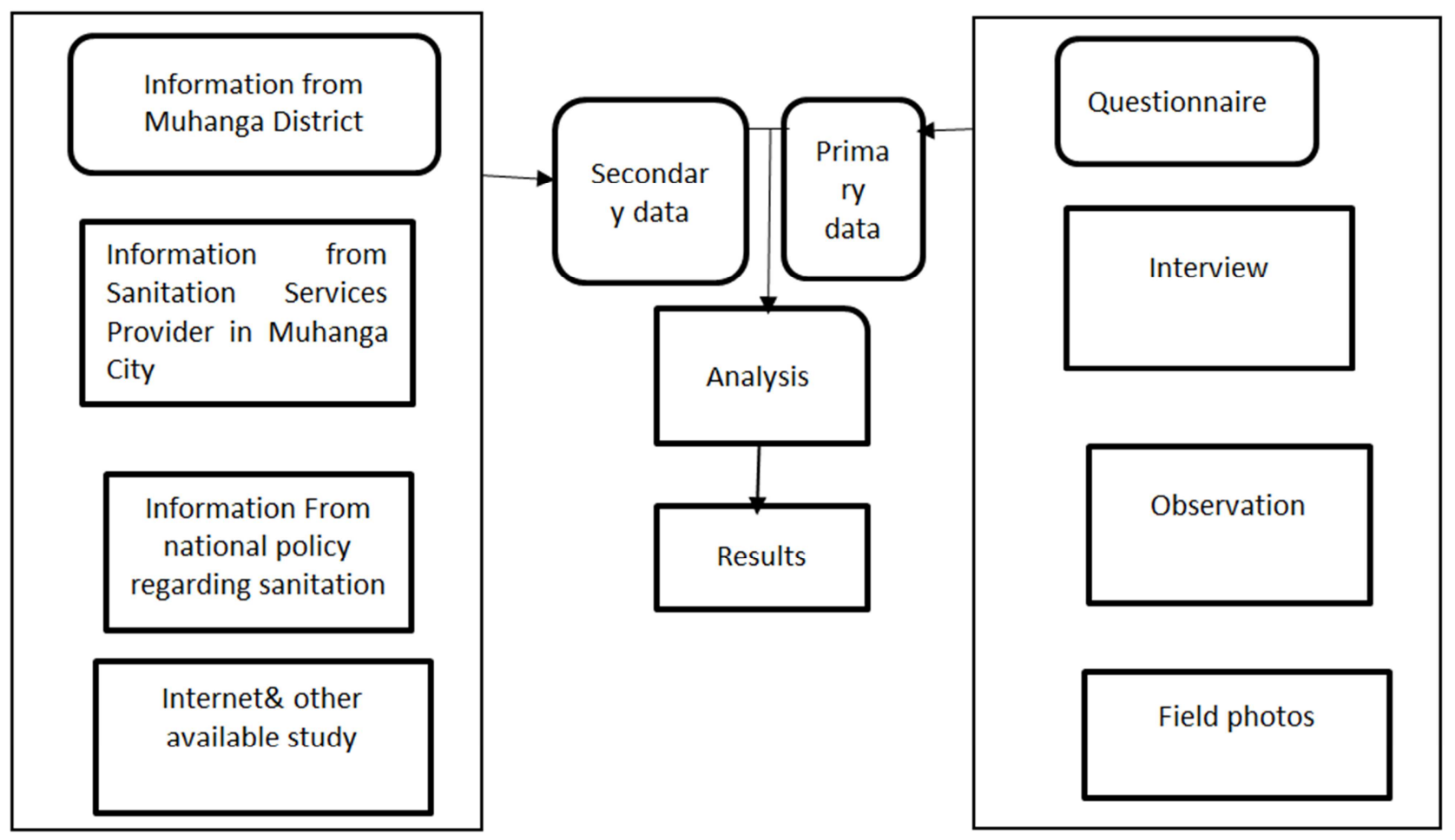

Figure 1. Summarized data collection and general approach for sanitation services.

For detecting land use land cover change for city development the following workflow will be used to compare map of year 2013 and 2017 using remote sensing technic. 


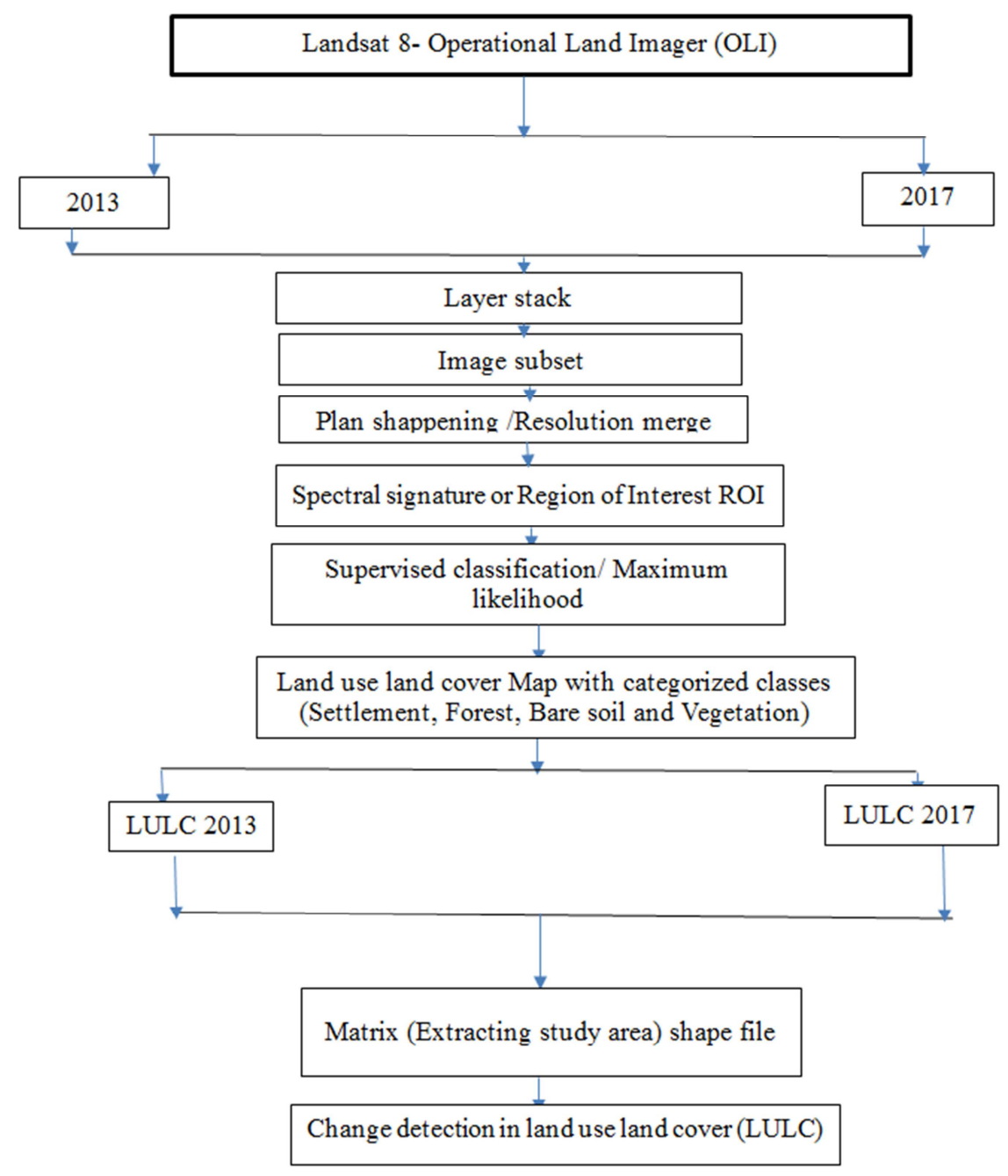

Figure 2. Schematic workflow used for LULC change detection.

\subsection{Data Analysis Procedures}

After the collection of the data we processed and analyzed them. We examined the raw collected data to detect errors and omissions, and correct them when necessary and possible. The data collected has been put in suitable tabulation and suitable graphs, and figures for analysis.

For survey questionnaire, coding booklet has been produced to assist in the analysis. The questions in the questionnaires was pre-coded and later tabulated. Tabulation was done so as to draw out the main themes according to individual questions in the questionnaire. Tables produced from the code booklet sought to draw out some statistical representation of variables that the questionnaires attempted to generate.

For all interviews, transcription was done to the data to identify main themes or ideas that the researcher sought. The presentation of data in the forms of tables and graphs only facilitates proper and easy analysis of data.

The obtained data were managed in Microsoft Excel in order to evaluate the relationship between city development and sanitation services and later subjected to the analysis of variance (ANOVA) by using GENSTART statistical package and the means were significantly separated by using Duncan's Multiple Ranges Test (DMRT) and the Least Significant Difference (LSD) has been considered at 0.05 level of confidence. Differences at probability less than 0.05 were considered significant.

In change detection analysis, remotely sensed data is useful to monitor the land use/land cover changes. The 2013 Landsat 8 and 2017 Landsat 8 data was used for reference. After the image classification step, the post classification change detection was performed and evaluated with "fromto" change information [7].

Artificial lakes classes are represented as water bodies' class in order to show the total change into construction.

\subsection{Situation and Physical Characteristics of the Study Area}

In order to provide a more balanced urban system, the Government of Rwanda announced, through EDPRS 2, the creation of six secondary cities. The goal of this strategic priority is to ensure more balanced urban growth for the country by encouraging the emergence of secondary economic poles of growth, while keeping the leading role of Kigali. To slow down the over-concentrated growth in Kigali 
and to leverage urbanization as a key factor in for the nation's economic transformation, the Government of Rwanda (GoR) has set a national target of 35\% urbanization by 2020 . In parallel, GoR has identified six secondary cities to become poles of growth: Huye, Muhanga, Nyagatare, Rubavu, Musanze, and Rusizi.

Muhanga is one of the six selected secondary city and is located in the southern province of Rwanda, it's also one of the eight districts comprising the Southern Province. It is subdivided into twelve (12) sectors, sixty-three (63) cells and three hundred and thirty-one (331) villages (Imidugudu). The District covers an area of six hundred forty-seven point seven square kilometers $\left(647.7 \mathrm{~km}^{2}\right)$ and, it is neighboring the Districts of Gakenke in the North, Kamonyi in the East, Ruhango in the South and Ngororero in the West.

This Secondary City is located fifty Kilometers $(50 \mathrm{~km})$ from the City of Kigali (CoK), Muhanga District is among the areas that supply the City of Kigali with food especially vegetables, fruit and meat of small livestock, mainly pork. Muhanga District is also located at the juncture between Kigali and the Southern and Western Provinces, the Republic of Burundi and Eastern of Democratic Republic of Congo. Major towns of Southern Province connected to Muhanga Secondary City are Ruhango, Nyanza, Huye and Nyamagabe, while those of the Western Province are Ngororero and Karongi. It is also connected to the Mayaga, region rich in agricultural production. This strategic location makes Muhanga Secondary City an economic pole that strives for development in trade and other businesses in the Southern part of the country by supplying goods and services but also a transit point for the supply of food in Kigali [8].

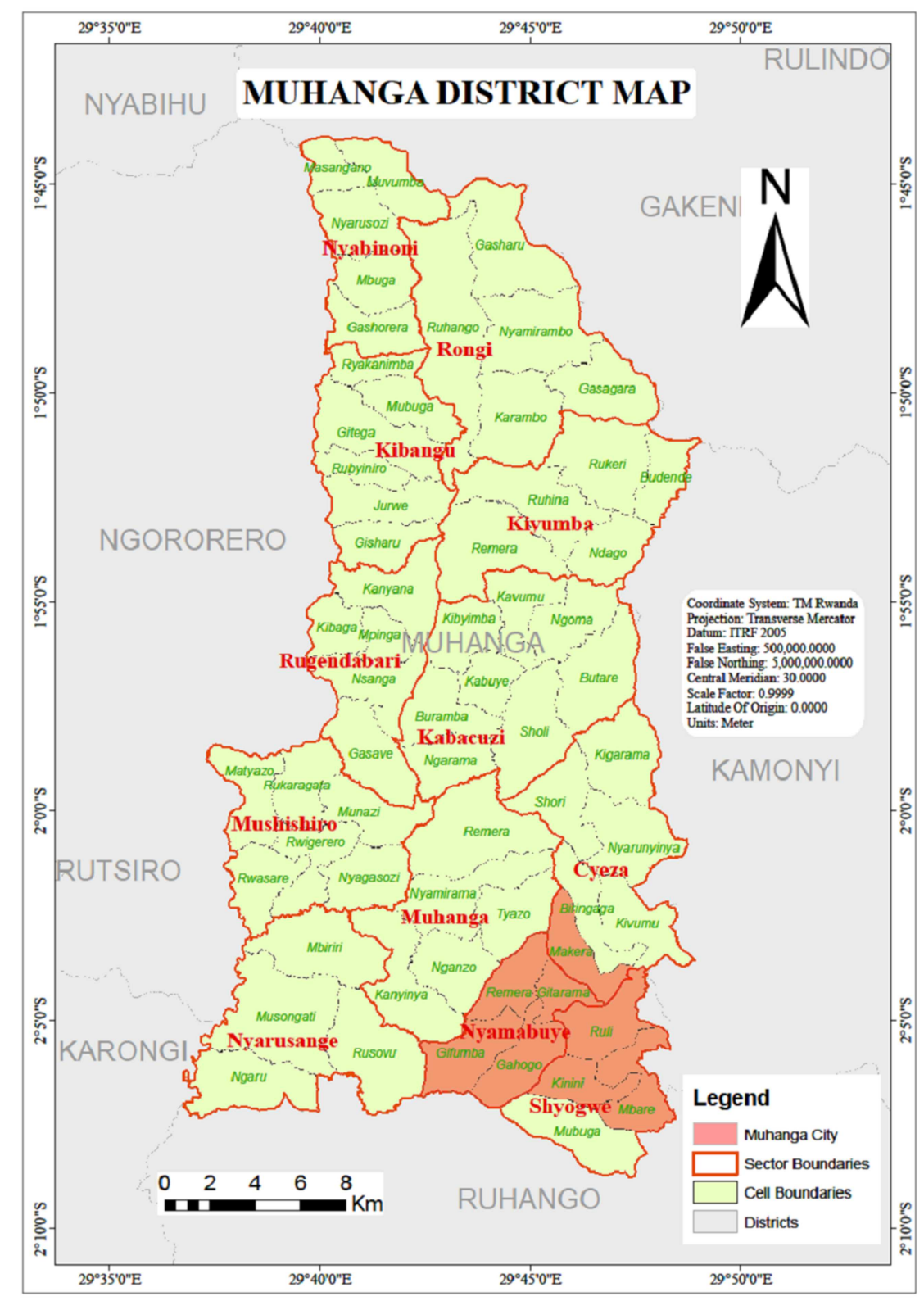

Figure 3. Map of Muhanga District. 


\section{Results and Discussion}

\subsection{Availability and Problems Relating to Sanitation at the City and Household Level}

\subsubsection{Overview of the Solid Waste Sector in Muhanga Town}

The Table below presents an overview of solid waste management practices in Muhanga city as captured from household survey, observation and discussion with focus group.

Table 1. Overview of solid waste management practices in Muhanga city.

\begin{tabular}{|c|c|}
\hline $\begin{array}{l}\text { Solid waste } \\
\text { generation }\end{array}$ & $\begin{array}{l}\text { Waste per capita: } 0.6 \mathrm{~kg} / \mathrm{day} \\
\text { Waste is not separated at source and it is collected mixed }\end{array}$ \\
\hline $\begin{array}{l}\text { Solid waste } \\
\text { composition }\end{array}$ & $\begin{array}{l}\text { Biodegradable are estimated to account for the highest share of the total waste: } 65 \% \text { of waste to landfill; } \\
\text { Waste in Muhanga is so divergent with more ash content. There are no much recyclables in Muhanga (Plastic 3\%; Paper } 0.5 \% \text { ) which } \\
\text { supports much effort to be oriented in composting initiatives. }\end{array}$ \\
\hline $\begin{array}{l}\text { Collection and } \\
\text { transportation }\end{array}$ & $\begin{array}{l}\text { Collection service coverage: } 9 \% \text {, Agruni is collecting waste in } 1116 \text { out } 12,376 \text { household of living in Muhanga urban area. } \\
\text { Waste collection service is provided by private companies: one company collecting solid waste from households, businesses, and road } \\
\text { sweeping activities; another company cleaning and collecting waste from district and sector offices } \\
\text { Used trucks: one roll-on-trucks owned by private companies is used to collect waste and because they are not partitioned all waste is } \\
\text { collected mixed. } \\
\text { Collection frequency: once a week or more than once a week (hotels, restaurants) based on negotiation. } \\
\text { Service reliability: irregular service due to weak physical capacity of the collection companies } \\
\text { User charges setting: district not involved in setting user charges, companies charges negotiated amount ranging from Frw } 1,000 \text { to } \\
4,000 \text { per month. }\end{array}$ \\
\hline $\begin{array}{l}\text { Waste-to- } \\
\text { resources }\end{array}$ & $\begin{array}{l}\text { waste-to-resources initiatives is low } 4 \% \text { use their generated waste as fertilizer, there is also small junk shops for metals and other } \\
\text { recyclables located in the public markets }\end{array}$ \\
\hline Waste disposal & $\begin{array}{l}\text { There is no landfill, waste is disposed in an open dumpsite, see figure } 6 \\
\text { All collected waste accumulates into an uncontrolled dumpsite exposed to children }\end{array}$ \\
\hline
\end{tabular}

\subsubsection{Solid Waste Generation and Handling}

The per capita Solid waste generation rate in Muhanga town, as obtained from the solid waste characterization field survey is $0.6 \mathrm{~kg} / \mathrm{cap} /$ day and from the preliminary data on solid waste management in Muhanga district, the estimate of $20 \mathrm{~m}^{3}$ is generated per day as reported by a company (Agruni) collecting waste from household.

In general, for 132 household sampled, 86 household their generated waste are composed by organic waste which is equal to $65 \%$, the amount of waste generated and type of waste constituents per person increases with increase in income and living condition. Other fine part including wood ashes (about $27 \%$ of generated waste equivalent to 36 household out of 132 sampled house) need special attention as illustrated on Figure 6.

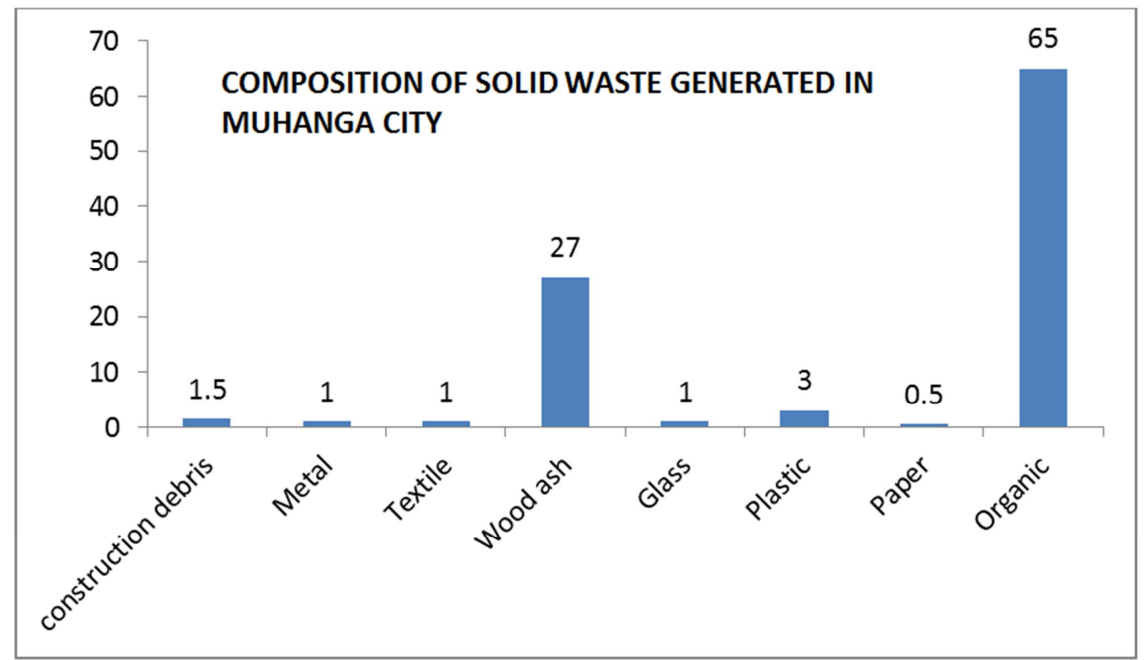

Figure 4. Composition Percentage of Solid waste Generated in Muhanga city.

Waste generated from households is stored in different containers including (but not limited to) bins and bags and placed inside their compound for collection by the waste collection operators' collection crews on the day of collection. Most households do not segregate recyclable waste in their premises. Waste collected from different shops is stored in their temporary dustbin before it is picked up by the cooperatives. The composition of organic waste is dominated by food waste.

This is also the case for the city of Muscat, Sultanate of 
Oman, where fractions of waste have been segregated in the collected sample. The major one is organic waste which accounts for $71.20 \%$ and $65.80 \%$ of the total MSW collected during the winter and summer respectively. On the other side, the inorganic fraction accounts for $28.80 \%$ and $34.20 \%$ in winter and summer respectively [9].

Composting is one of the preferred methods for reducing biodegradable organic material. As it can reduce more than $50 \%$ of biodegradable organic components of SW on-site. Composting decreased the residential SW between 38 and $55 \%$ in Dar es Salaam city, Tanzania [10], composting in most developing countries occurs at household level [11].

\subsubsection{Solid Waste Collection and Transportation}

The collection service coverage in Muhanga totaling $9 \%$ of the city dwellers. In 132 household sampled only 12 household is in this mechanism of waste collection at household level. The same service coverage has been reported by the private company (Agruni) that provides collection service to households and small businesses through cleaning contract; 1116 households out of the of 12,376 Households populating Muhanga city (9\%) have contract with Collection Company. even though there is progress as this practice is new in this city, there is a long way to go up to $100 \%$ service coverage which is the target of the district by 2024 .

The same low service collection coverage have been reported by various researchers; that collection rate in lowincome countries ranges from 35-68\% [12], [13].

Limited service coverage in Muhanga city is explained by various factors from which service affordability account for $32 \%$ and for the quantity of waste generated $(28 \%)$ are the main factors as summarized in Figure 5.

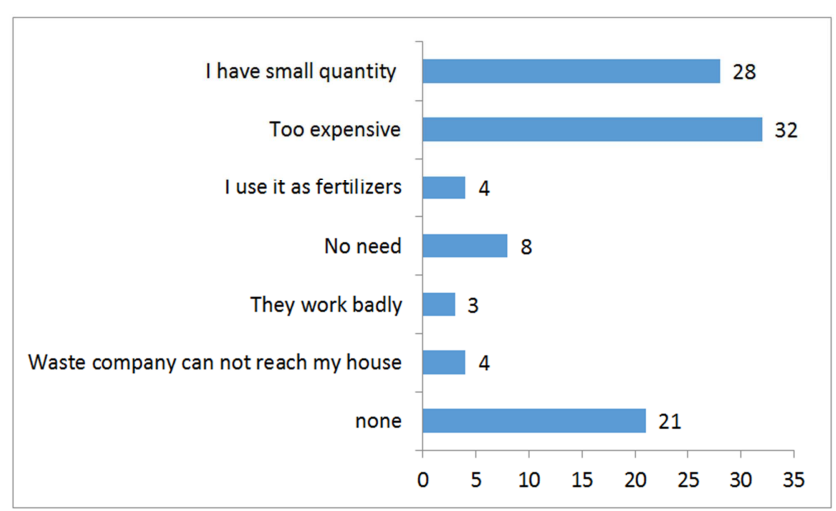

Figure 5. Factors influencing service coverage for solid waste collection in Muhanga city.

Although some households separate waste, the fact that waste is mixed during collection and transportation and the fact that waste is mixed at the dumpsite, lead to the drawback attitudes of households to separating waste. The collection company owns only one small, old and non-partitioned collection truck which leads to poor quality service and mixed waste collection.

Moreover, households have reported that the collection company does not respect the waste collection schedules of the week to the extent that they can skip service up to five days while waste is placed at the collection point as agreed during contract negotiation. Some households have also argued that the company pours collected waste in open field after collecting it from the citizens. This pushes most of the citizens both contracted and non-contracted throwing their solid waste in the forests or other free lands.

Considering the National population Census of 2012, Muhanga district has 12,376 households populate in the city. This means that only once collection truck is used to service about 12,376 households. The company has reported that it services 67 households /trip and makes 3 trips per day. This means that 201 households are serviced per day. Assuming that all 12,376 households have contract with waste collection company, using one truck would require 61 days to service all households. It is then clear that the company needs to have other trucks to serve households and at least one truck to provide service to businesses. It is also clear that to increase service coverage requires working on building the capacities of service providers, willingness of households and on regulatory framework, especially setting affordable prices. This is also explained by the newly urbanizing areas of Muhanga which record a big fraction of urban population living informal settlement with limited ability to pay the service as it is the case for other East African community countries [14].

\subsubsection{Solid Waste Disposal Site}

As discussed above, Muhanga city has no sanitary landfill and all collected waste ends into uncontrolled dumpsite located at Kanyinya sector in $12 \mathrm{~km}$ from city center. The dumpsite does not have a fence which allows children to scavenge on dumped waste associated with limited access due to unpaved road from the main road to the dumpsite.

[15] Argue that the main challenges for developing countries to improve disposal are related to the governance. The high capital investment and operational costs for dump sites require a strong commitment of governments which is lacking for many developing countries and Rwanda is no exception as waste competes with other development activities.

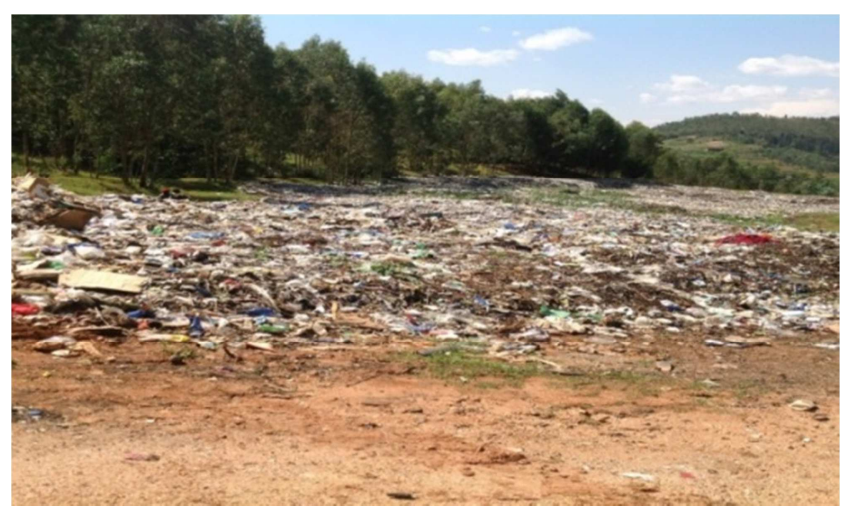

Figure 6. Dumpsite located at Kanyinya cell in Muhanga Sector of Muhanga District.

Waste ending in that dumpsite is dominated by organic component as illustrated in figure 4 (about $65 \%$ of generated 
waste) but some other components including wood ashes (about 27\%), Muhanga district has contracted a private company to manage this dumpsite. The manpower of the company separate waste and give organic waste to households free of charge based on their written request as mentioned above. Waste Collection Company does not pay tipping fee. The district has completed a feasibility study of improved landfill but no funds were secured to implement the proposed plan.

The financial limitation is the main challenge for many developing country cities and Muhanga is no exception for the above-mentioned project to improve the dump site by integrating the composting, the design of the landfill has been developed by the consultant as requested by the District, but the implementation failed due to the lack of the budget.

For households, the survey conducted in 132 sampled house showed that their generated solid waste are disposed in different ways as follows: $37 \%$ dispose solid waste in open field, 34\% households dispose it in compost well, 8.6 households dispose it at road side, $11 \%$ dispose it in drainage, and $9.4 \%$ dispose it in waste container then later collected by a private company in charge of collecting solid waste at household level

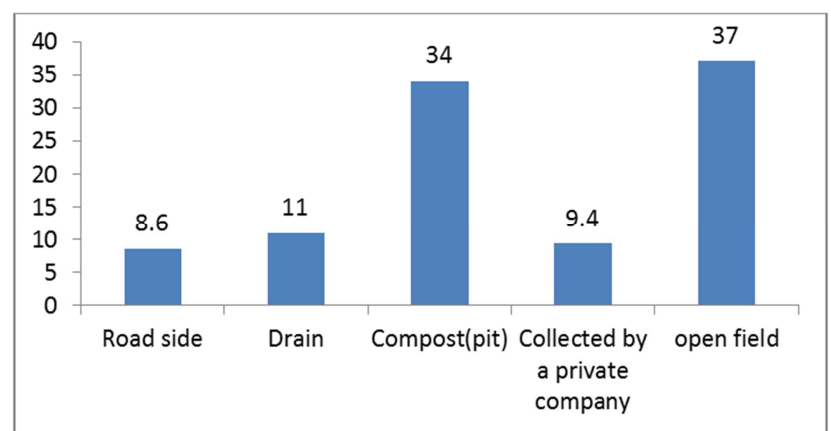

Figure 7. Percentage of different ways of solid waste disposal in Muhanga.

In fact, based on the composition of waste generated in Muhanga, and based on the fact that the main economic activity of Rwanda is agriculture, solid waste would not be a problem. Like for other waste generated in East African cities such as in Uganda, organic waste represent a big quantity, in Muhanga $65 \%$ of waste generated is organic. This means that the composting can importantly reduce the effect of solid waste disposal on the environment as the technical viability has been evidenced in Uganda and Tanzania [16] [17].

\subsubsection{Storm Water Management}

In 132 household surveyed, 54.2\% stated that storm water is not a problem in their localities but $39.2 \%$ of households said that storm water is a problem and $6.6 \%$ did not respond to the question. Refers to the effects related to storm water, $51.5 \%$ of respondents said that it overflow on side walk, $38 \%$ stated that there is no drainage systems in their localities, $5 \%$ said that storm water is flooding into their houses, $5.5 \%$ said that there is no problem

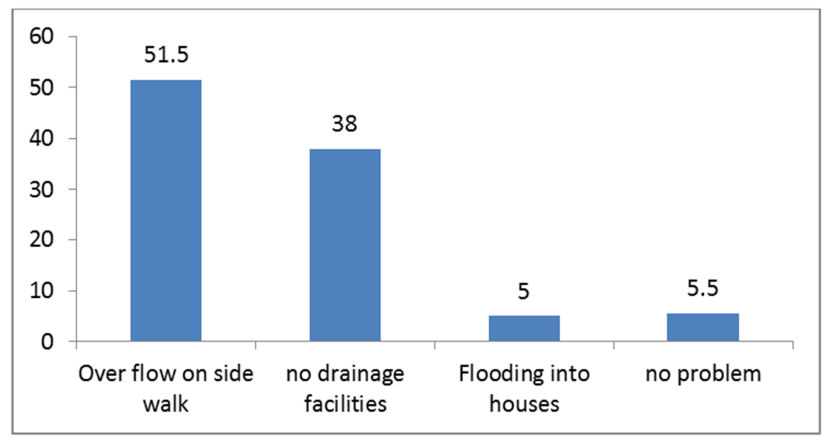

Figure 8. Problem related to storm water management in Muhanga city.

To reduce this storm water effect, people need to harvest their rooftop rain water, and the District has to construct more standalone drainage in the area with no drainage especially in informal settlement sites. In order to face the challenges posed by urban storm water, new techniques must be adapted to local constraints and be an integral part of the city's urban plan [18].

In addition to treating flooding and pollution issues [19] highlight three main benefits of sustainable storm water management: Urban and landscape aesthetic with the reintroduction of nature in the city; promotion of storm water as a useful resource; and climate regulation interests; with most techniques combining several of these benefits. Cost optimization and environmental education are also aspects that have to be taken into consideration when implementing sustainable storm water management.

\subsection{Development of Muhanga City and Factors Leading to It Growth}

\subsubsection{Land Use Land Cover Change Detection Between 2013 and 2017}

With the use Landsat Thematic Mapper (TM) images acquired from the years 2013 and 2017 was used with Landsat Operational Land Imager (OLI) at a resolution of $30 \mathrm{~m}$ for the years 2013 and 2017 in LULC classification. All required satellite imagery for the study area was downloaded from the official site of USGS earth explorer. The city plan was obtained from the Muhanga urban area shape file of study area. In this study, the remote sensing software ERDAS was used for image processing. During the process, the imagery geometrically corrected through pre-processing calibration, which consist of atmospheric and topographic correction.

The basic image processing steps applied in order to determine and analyse the changes due to city development are given in figure 9 for the year 2013 and figure 10 for the year 2017 and explained in the following subsections briefly. 


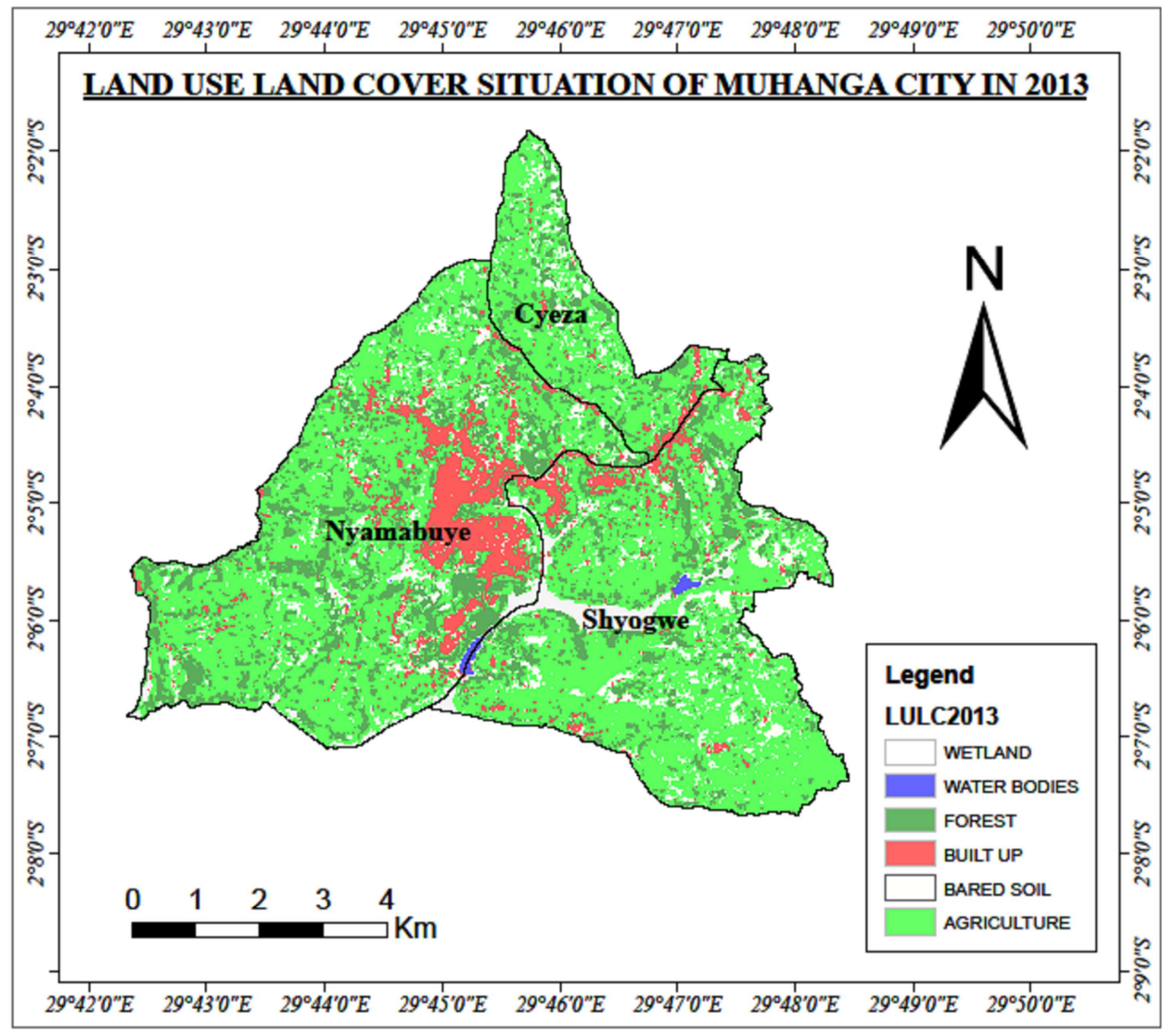

Figure 9. Land use land cover situation map of Muhanga city in 2013.

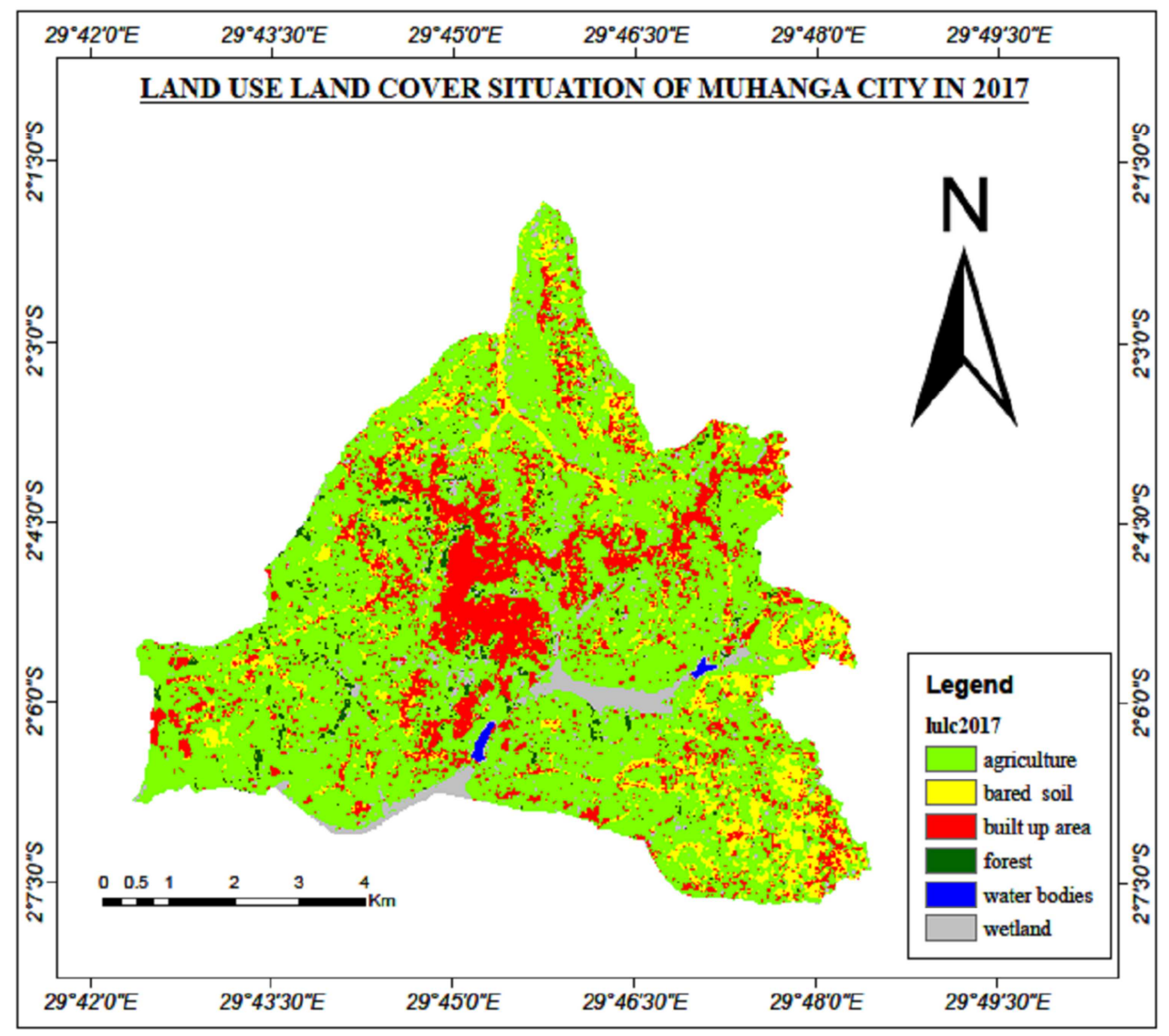

Figure 10. Land use land cover situation map of Muhanga city in 2017. 
The table below illustrate results of land use situation for the year 2013-2017 in the six identified classes

Table 2. Results of land use situation in 2013 and 2017 in six classes identified.

\begin{tabular}{|c|c|c|c|c|}
\hline NO & CLASS_NAMES & NUMBER OF PIXELS & area (ha) & $\%$ \\
\hline \multicolumn{5}{|c|}{2013} \\
\hline 1 & Agriculture & 167131 & 3605.716423 & $61.39 \%$ \\
\hline 2 & Bared soil & 24890 & 536.9816597 & $9.14 \%$ \\
\hline 3 & Built up & 24955 & 538.3839823 & $9.17 \%$ \\
\hline 4 & Forest & 43963 & 948.4662397 & $16.15 \%$ \\
\hline 5 & Water bodies & 780 & 16.82787041 & $0.29 \%$ \\
\hline 6 & TOTAL & 260939 & 5629.548305 & $100.00 \%$ \\
\hline \multicolumn{5}{|c|}{2017} \\
\hline 1 & agriculture & 177070 & 3820.142326 & $65.04 \%$ \\
\hline 2 & bared soil & 30331 & 654.366843 & $11.14 \%$ \\
\hline 3 & built up area & 48547 & 1047.36234 & $17.83 \%$ \\
\hline 4 & forest & 4742 & 102.3048224 & $1.74 \%$ \\
\hline 5 & water bodies & 600 & 12.9445157 & $0.22 \%$ \\
\hline 6 & TOTAL & 272250 & 5873.573518 & $100.00 \%$ \\
\hline
\end{tabular}

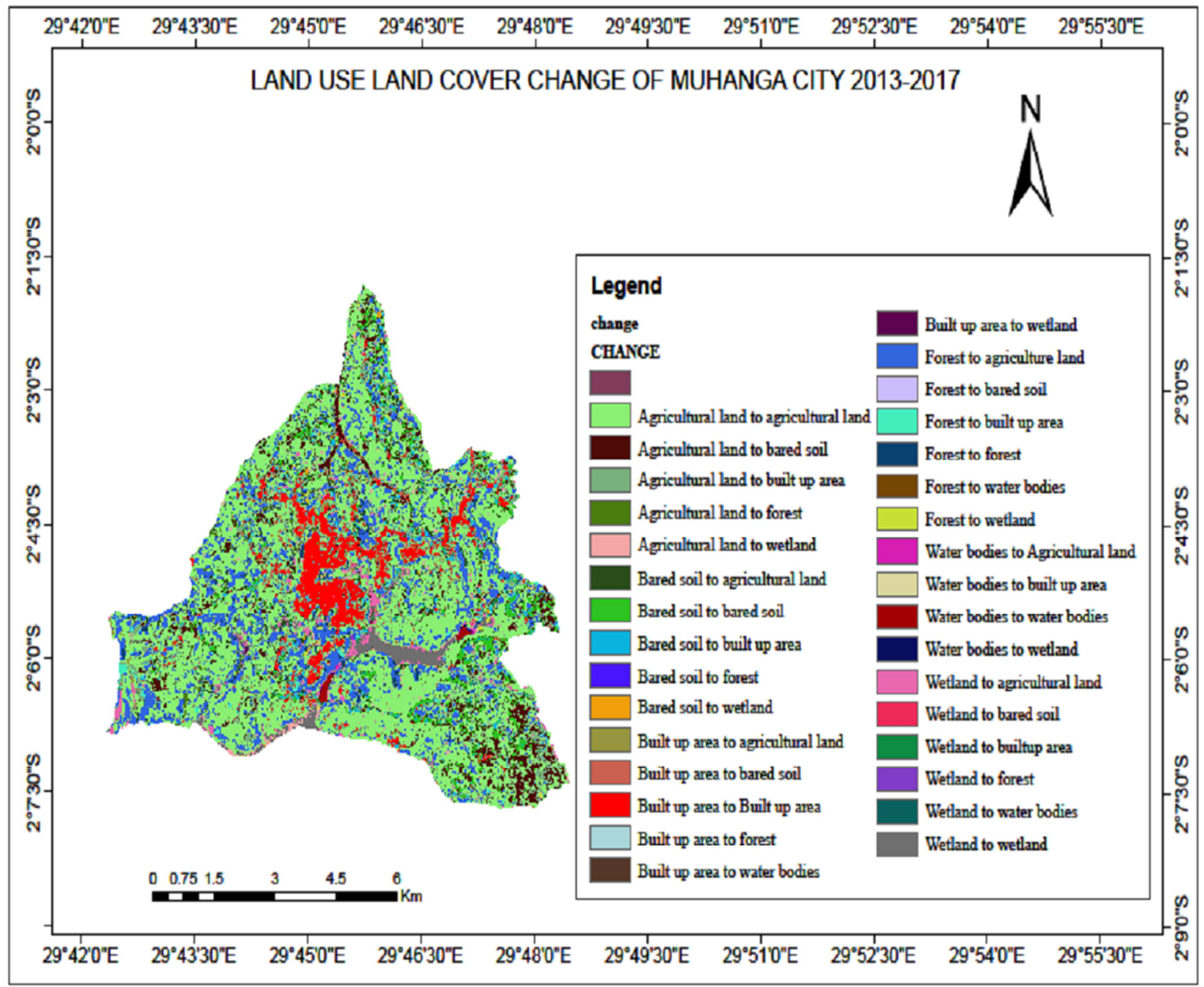

Figure 11. Land use land cover change map of Muhanga City 2013-2017.

By comparing land cover situation of 2013 and 2017 the following change has been identified: 
Table 3. Land use land cover change of Muhanga city 2013-2017.

\begin{tabular}{|c|c|c|c|c|}
\hline No & CHANGE & COUNT & AREA (ha) & $\%$ \\
\hline 1 & Bared soil to bared soil & 8881 & 191.60 & $3.26 \%$ \\
\hline 3 & Bared soil to forest & 20 & 0.43 & $0.01 \%$ \\
\hline 4 & Bared soil to wetland & 622 & 13.42 & $0.23 \%$ \\
\hline 6 & Bared soil to agricultural land & 8235 & 177.66 & $3.02 \%$ \\
\hline 8 & Water bodies to water bodies & 573 & 12.36 & $0.21 \%$ \\
\hline 10 & Water bodies to wetland & 132 & 2.85 & $0.05 \%$ \\
\hline 12 & Water bodies to Agricultural land & 66 & 1.42 & $0.02 \%$ \\
\hline 13 & Forest to bared soil & 57 & 1.23 & $0.02 \%$ \\
\hline 14 & Forest to water bodies & 1 & 0.02 & $0.00 \%$ \\
\hline 15 & Forest to forest & 2757 & 59.48 & $1.01 \%$ \\
\hline 16 & Forest to wetland & 1223 & 26.39 & $0.45 \%$ \\
\hline 17 & Forest to build up area & 2813 & 60.69 & $1.03 \%$ \\
\hline 18 & Forest to agriculture land & 37112 & 800.65 & $13.63 \%$ \\
\hline 19 & Wetland to bared soil & 90 & 1.94 & $0.03 \%$ \\
\hline 21 & Wetland to forest & 163 & 3.52 & $0.06 \%$ \\
\hline 22 & Wetland to wetland & 4798 & 103.51 & $1.76 \%$ \\
\hline 23 & Wetland to built-up area & 740 & 15.96 & $0.27 \%$ \\
\hline 24 & Wetland to agricultural land & 4725 & 101.94 & $1.74 \%$ \\
\hline 25 & Built up area to bared soil & 1649 & 35.58 & $0.61 \%$ \\
\hline 26 & Built up area to water bodies & 11 & 0.24 & $0.00 \%$ \\
\hline 27 & Built up area to forest & 25 & 0.54 & $0.01 \%$ \\
\hline 28 & Built up area to wetland & 262 & 5.65 & $0.10 \%$ \\
\hline 29 & Built up area to Built up area & 20099 & 433.62 & $7.38 \%$ \\
\hline 30 & Built up area to agricultural land & 2909 & 62.76 & $1.07 \%$ \\
\hline 31 & Agricultural land to bared soil & 19654 & 424.02 & $7.22 \%$ \\
\hline 33 & Agricultural land to forest & 1777 & 38.34 & $0.65 \%$ \\
\hline 34 & Agricultural land to wetland & 3923 & 84.63 & $1.44 \%$ \\
\hline 35 & Agricultural land to built up area & 17754 & 383.02 & $6.52 \%$ \\
\hline 36 & Agricultural land to agricultural land & 124023 & 2675.67 & $45.55 \%$ \\
\hline
\end{tabular}

\subsubsection{Change Detection Analysis}

During the 5 years period (2013 to 2017), settlement area increased by around $8.67 \%$, On the other hand, Forest decreased by $14.41 \%$ in area. Water bodies recorded minimum change according to deforestation in land use in the study area, while Agriculture increased by over $3.65 \%$ in the area as represented in table 2. Increased agriculture area refers to the factor of deforestation.

The rapid expansions in settlement area noted during evaluation of classified images between 2013 to 2017 is mainly caused by economic prosperity and population growth. Change in settlement area returns to modification of land cover due to human processes. While the change in Forest decreased in area from 2001 to 2017 due to the plan to increase agriculture land and built up area as represented in table 3.
In situations of rapid land use change, the classified images provide detail information to understand the land use and land cover of the study area. Built up area in Muhanga city expended significantly from the years 2013 to 2017 . This expansion occurred comes at the expense of the agriculture land, bare soil and forest shortage.

\subsection{Relationship Between city Development and Sanitation}

The table 4 illustrate the link between population growth of Muhanga urban area and the quantity of waste produced, based on the recorded data of private company who is in charge of managing the dumpsite, it is clear that solid waste is increasing with the increase of population and it varied from 1,555 cubic meter in 2014 to 3,045 cubic meter in 2017. The data of waste produced in 2013 was not recorded.

Table 4. Link between population growth and waste production.

\begin{tabular}{lllll}
\hline Year & $\mathbf{2 0 1 4}$ & $\mathbf{2 0 1 5}$ & $\mathbf{2 0 1 6}$ & $\mathbf{2 0 1 7}$ \\
\hline population & 51,727 & 52,296 & 52,871 & 53,453 \\
waste production $\left(\mathrm{m}^{3} /\right.$ year $)$ & 1,555 & 1,695 & 2,630 & 3,045 \\
\hline
\end{tabular}

The population of Muhanga urban area in 2012 was 50,608 and the growth rate was $1.1 \%$ (NISR, 2012), the exponential model formula was adopted for estimating future populations for the next 4 years. The ANOVA results shows that the amount of waste generation is significantly difference between the year 2014 and the year 2017, the probability is equal to $(p=0.026)$, the remaining year the difference was not significant as the probability was greater than the fixed 
level of confidence $(\mathrm{p}>0.05)$

Basing on the current pace of city development, waste prevention is the preferred municipal solid waste management technique and requires source reduction in the design, manufacture, purchase, or use of materials and products in order to reduce the amount and/or toxicity of discarded waste by not producing.

According to [20] source reduction involves reuse activities and "has come to be recognized as a commonsense approach with significant potential to use resources efficiently, save money, and reduce waste" and because of the various advantages it presents, many states in the United States of America (USA) have increasingly engaged in innovative ventures towards solid waste prevention. Grass cycling and backyard composting are taken to be "forms of source reduction or waste prevention because the materials are completely diverted from the disposal facilities and require no municipal management or transportation.

\section{Conclusion}

This research was conducted on the assessment of the impact of Muhanga city development on sanitation services, the primary data regarding sanitation was collected using questionnaire survey, interviews and observation. To evaluate land use land cover situation from the year 2013 up to 2017 remote sensing techniques was used.

The results from collected data showed that $65 \%$ of generated solid waste is composed by organic waste, while waste collection coverage from household level is low with a percentage of $9 \%$. The analysis of land use land cover situation showed that during the five years, settlement area increased by $8.67 \%$, the amount of waste generation is increasing with population growth, and it varied from $1,555 \mathrm{~m}$ 3 in 2014 to $3,045 \mathrm{~m} 3$ in 2017.

The analysis of variance (ANOVA) results shows that the amount of solid waste generated is significantly difference between the year 2014 and the year 2017 .

Regarding liquid waste management there are drainage systems constructed, although the survey made showed that $39.2 \%$ of households sampled highlighted that storm water is still a problem in their residential area.

The obtained results evidenced that solid waste collection at household level by a private company is a new practice in the city, and the collection coverage is still low compared to city resident, consequently there is still informal dumpsite in open area across the city.

The private sector needs to be more committed in sanitation services provision, and the public sector needs to be involved in sanitation infrastructures development by focusing on composting facilities as a big percentage of generated waste is biodegradable. The public sector has a direct influence on the private sector and the community, the community and the private sector need to become familiar with working together for the purpose of improving sanitation with the aim to protect the environment.

\section{Recommendations}

This study has generated a number of issues and questions, it is clear that in terms of environmental aspect there is a need to improve the final disposal to prevent the impact to the solid waste collectors, environment and public health in general environmental hazards related to mismanagement of the dump site but also to the low capacity of the dump site to receive all collected waste.

Basing on the findings of this research, in order to improve sanitation in the city; the following recommendation have to be implemented:

a) Construct waste management infrastructures like sewers pipelines to transport waste water, public toilets and landfill with much emphasizing on composting facilities as much as waste generated is biodegradable and plan for recycling of non-biodegradable waste. Meanwhile as a temporary solution to this problem, Muhanga District could initiate a memorandum of understanding of collaboration with Ruhango District to use their landfill. Ruhango landfill is located in $30 \mathrm{~km}$ from Muhanga city. In general, Ruhango is a small city. This is an advantage to Muhanga as far as solid waste is concerned because the capacity of the landfill is big compared to the size of the city.

b) The District Council could set fees for collecting waste at household level and penalties to household not involved in this waste collection mechanism

c) Since disposal / composting of biodegradable wastes will continue to be conducted at the existing dumpsites, they should be upgraded to have a lined base layer in order to avoid ground water pollution. There should also be leachate control and treatment to avoid surface water pollution.

d) Construct fences and hire security guards to avoid unauthorized access to the used open dumpsites

e) Encourage the local people to do sorting at the source of solid wastes (use bags of different colours for different types of wastes). This will help to identify / separate biodegradable and non-biodegradable easily.

\section{Acknowledgements}

Special thanks go to all Muhanga District staff working in urbanization and sanitation department, but also to UNILAK staff for constant help and cooperation received in setting up the study, I would like to express my thanks to all academic staff of Master of Science in Environment and Development Studies; Option of Environmental Economics and Natural Resources Management for their skills provided to accomplish my work.

We feel highly indebted and full of gratitude to my Family, Colleagues, Friends and the staff of Muhanga District for their great helps to reach on the end of this research. Last but not the least, my deep sense of gratitude is due to anyone who either directly or indirectly has contributed to the progress and financial assistance of this work. 


\section{References}

[1] WHO, (2015). Progress on Sanitation and Drinking Water: 2015 Update and MDG Assessment. World Health Organization.

[2] Government of Rwanda and GGGI (2015). National Roadmap for Green Secondary City Development. Kigali.

[3] NST 1 (2018). National Strategy for transformation, Kigali. Rwanda.

[4] NISR, (National Institute of Statistics of Rwanda), Establishment Census, 2012.

[5] Oteng-Ababio M. (2009) Private sector involvement in solid waste management in the greater Accra Metropolitan Area in Ghana. Waste management \& Research 28 (4): 322-9 doi: $10.1177 / 0734242 X 09350247$.

[6] Bryman, A. (2008). Social Research Methods, 3rd edition, Oxford University Press.

[7] Macleod, R. D., and Congalton, R. G., 1998. A quantitative comparison of change-detection algorithms for monitoring eelgrass from remotely sensed data. Photogrammetric Engineering and Remote Sensing, 64 (3), pp. 207-216.

[8] Muhanga District, (2018) District Development strategy (2018-2024), Rwanda.

[9] Thenmozhi Murugaian Palanivel and Hameed Sulaiman, 2014. Generation and Composition of Municipal Solid Waste (MSW) in Muscat, Sultanate of Oman.

[10] Mbuligwe, S. E., G. R. Kassenga, M. E. Kaseva, E. J. Chaggu, 2002. Potential and constraints of composting solid waste in developing countries: findings from a pilot study in Dar es Salaam, Tanzania. Resources, Conservation and Recycling, 36: 45-59.

[11] Augestien, D., D. L. Wise, N. X. Dat, N. D. Khien, 1996. Composting of municipal solid waste and sewage sludge: potential for fuel gas production in a developing country. Resources, Conservation and Recycling, 16: 265-279.
[12] Scheinberg A., Spies S., Simpson M. H., Mol A. P. J. (2011) Assessing recycling in low- and middle-income countries: Building on modernized mixtures. Habitat International, 35 (2) (2011), pp. 188-198.

[13] Vidanaarachchi C. K., Yuen S. T. S., \& Pilapitiya, S. (2006) Municipal solid waste management in the southern province of Sri Lanka: Problems, issues, and challenges. Waste Management 26: 920-930.

[14] Okot-Okumu J., 2008. Solid waste Management in Uganda: Issues Challenges and Opportunities. POVIDE program Workshop. The Netherlands.

[15] Wilson C. D., Velis C. A., Rodic L., (2013) Integrated sustainable waste management in developing countries. Waste Resour. Manage. 166 (WR2).

[16] Kumar S. N (2006) Report on Setting up compost Plants for Municipal Solid wastes in Uganda. EMCBP- II World Bank \& National Environment Management Authority, Kampala Uganda.

[17] Oberlin A. S., \& Sza'nto' G. L., 2011. Community level composting in a developing country: a case study of KIWODET, Tanzania. Waste Management \& Research. 29 (10) 1071-1077.

[18] Lami, M., Vigneron, S., Brelot, E., Bacot, L., Chapgier, J., Sibeud, E., Barraud, S., Pionchon, P., Clabaut, A., Cambon, A. and Ricard, B. (2006) 'Pour la gestion des eaux pluviales Stratégie et solutions techniques'. Charbonnières-les-Bains: Région Rhône-Alpes. Available at: http://www.graie.org/graie/graiedoc/doc_telech/PlaqTA.pdf.

[19] Chocat, B., Krebs, P., Marsalek, J., Rauch, W., \& Schilling, W. (2001). Urban Drainage redefined: from stormwater removal to integrated management. Water Science and Technology Vol. 43 No 5, pp. 61-68.

[20] United States Environmental Protection Agency (USEPA) (2002) Solid Waste Management: A Local Challenge with Global Impacts, Washington D. C. Solid Waste and Emergency Response URL: http://www.epa.gov/epaoswer/non-hw/muncpl/ghg/f02026.pdf Accessed 19th October, 2018. 